\title{
Designing Deliberation Systems
}

\author{
Rose, Jeremy; Sæbø, Øystein
}

Published in:

The Information Society

DOI (link to publication from Publisher):

10.1080/01972241003712298

Publication date:

2010

\section{Document Version}

Publisher's PDF, also known as Version of record

Link to publication from Aalborg University

Citation for published version (APA):

Rose, J., \& Sæbø, Ø. (2010). Designing Deliberation Systems. The Information Society, 26(3), $228-240$. https://doi.org/10.1080/01972241003712298

\section{General rights}

Copyright and moral rights for the publications made accessible in the public portal are retained by the authors and/or other copyright owners and it is a condition of accessing publications that users recognise and abide by the legal requirements associated with these rights.

- Users may download and print one copy of any publication from the public portal for the purpose of private study or research.

- You may not further distribute the material or use it for any profit-making activity or commercial gain

- You may freely distribute the URL identifying the publication in the public portal -

\section{Take down policy}

If you believe that this document breaches copyright please contact us at vbn@aub.aau.dk providing details, and we will remove access to the work immediately and investigate your claim. 
This article was downloaded by: [Rose, Jeremy][Aalborg University]

On: 28 April 2010

Access details: Access Details: [subscription number 912902582]

Publisher Routledge

Informa Ltd Registered in England and Wales Registered Number: 1072954 Registered office: Mortimer House, 3741 Mortimer Street, London W1T 3JH, UK

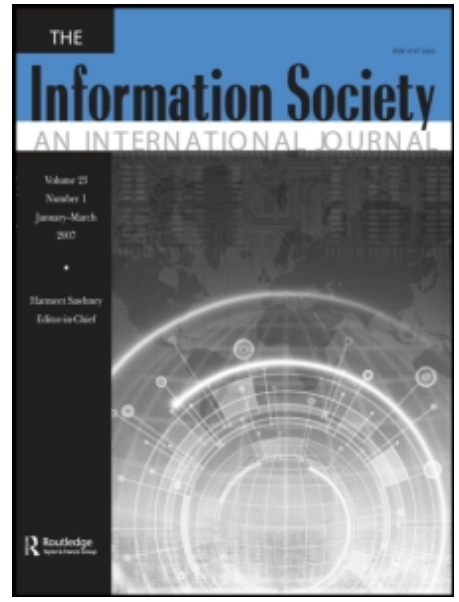

\section{The Information Society}

Publication details, including instructions for authors and subscription information:

http://www.informaworld.com/smpp/title content=t713669588

\section{Designing Deliberation Systems}

Jeremy Rose ${ }^{\mathrm{a}}$,Øystein Sæbø ${ }^{\mathrm{b}}$

${ }^{a}$ Department of Computer Science, Aalborg University, Aalborg, Denmark bepartment of

Information Systems, University of Agder, Kristiansand, Norway

Online publication date: 27 April 2010

To cite this Article Rose, Jeremy andSæbø, Øystein(2010) 'Designing Deliberation Systems', The Information Society, 26: 3, $228-240$

To link to this Article: DOI: $10.1080 / 01972241003712298$

URL: http://dx.doi.org/10.1080/01972241003712298

\section{PLEASE SCROLL DOWN FOR ARTICLE}

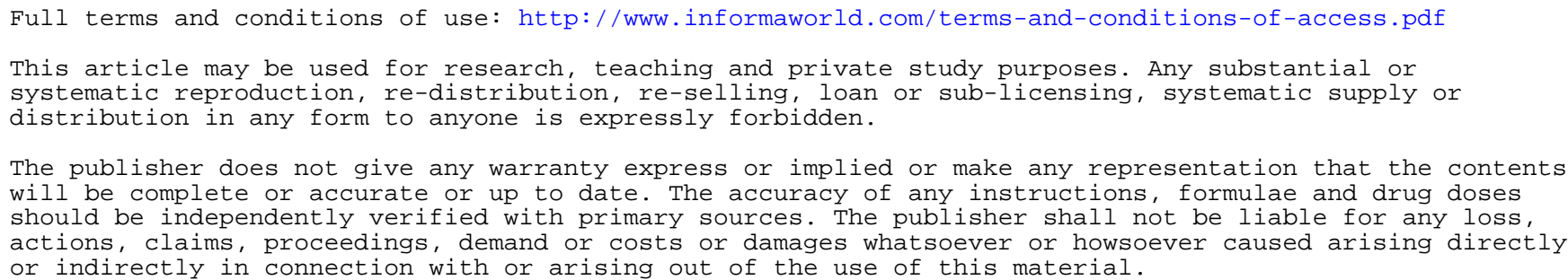




\title{
PERSPECTIVE
}

\section{Designing Deliberation Systems}

\author{
Jeremy Rose \\ Department of Computer Science, Aalborg University, Aalborg, Denmark
}

\section{Øystein Sæbø}

Department of Information Systems, University of Agder, Kristiansand, Norway

In a liberal democracy, the evolution of political agendas and formation of policy involves deliberation: serious consideration of political issues. Modern-day political participation is dependent on widespread deliberation supported by information and communication technologies, which also offer the potential to revitalize and transform citizen engagement in democracy. Although the majority of Web 2.0 systems enable these discourses to some extent, government institutions commission and manage specialized deliberation systems (information systems designed to support participative discourse) intended to promote citizen engagement. The most common examples of these are political discussion forums. Although usually considered trivial adaptations of well-known technologies, these types of deliberative systems are often unsuccessful, and present a distinct set of design and management challenges. In this article, the authors analyze the issues involved in establishing political deliberation systems under four headings: stakeholder engagement, Web platform design, service management, political process reshaping, and evaluation and improvement. We review the existing literature and present a longitudinal case study: the Norwegian Demokratitorget (Democracy Square). We define key issues in each of the four areas, which need to be understood to design and manage a successful net-based deliberation forum.

Keywords deliberation systems, e-participation, political discussion forums, system design, system management

Received 6 May 2009; accepted 29 January 2010.

This research was in part sponsored by Demo-net, the European Network of Excellence in e-participation. Thanks in particular to Georg Aichholzer and Maung K. Sein for comments and suggestions.

Address correspondence to Jeremy Rose, Aalborg University, Selma Lagerløfs Vej 300, 9220 Aalborg, Denmark. E-mail: jeremy@cs.aau.dk
Democracy can be understood as "the institutionalisation of a public use of reason jointly exercised by autonomous citizens" (Habermas 1999, 351). In this understanding, a democracy "proceeds by public argument and reasoning" (Coben 2003, 345) — where an important part of civic participation involves widespread public deliberation. The lack of this form of citizen engagement is assumed to result in democratic deficit: decrease in political engagement, disconnection between citizens and their elected representatives, and a consequent decline in the legitimacy of political institutions. Information and communication technologies (ICT) - particularly the Internethave an important role to play in supporting deliberation. These technologies offer the potential for widespread direct citizen participation in political decision makingpotentially transforming the shape of democracy. They can both deliver conventional forms of discourse to a wider audience and offer new opportunities for political participation. Spontaneous citizen-driven deliberation (Avdic, Hedström, and Grönlund 2007) is widespread on the net through the various forms of Web 2.0 communication and user-generated content (blogging, social software, etc.), enabling networked individuals to go beyond the boundaries of existing political institutions (Dutton and Eynon 2009). However, governments also sponsor e-participation initiatives that seek to improve citizen engagement in the political process; these initiatives potentially have a privileged character because participation here can have a direct influence on decision making. The preferred vehicle for this kind of deliberation has been the political discussion forum, and all technologically advanced democracies have these systems, at local, regional national, and supernational levels. In this article we focus on the design and management of purpose-built deliberation systems by and on behalf of government. 
Though no comprehensive evaluation of these projects exists, it is clear that many initiatives are rather unsuccessful. The technology platform appears deceptively simple and inexpensive to implement; the majority of efforts fail to attract widespread interest among citizens or politicians, are unrepresentative (Dahlberg 2001), lead to poor information (Koch 2005) or poor quality of debate (Hagemann 2002), are monopolized by a few vocal contributors (Hagemann 2002), or have security and trust issues-particularly if there is a voting component (Xenakis and MacIntosh 2005). In this article we provide a practically oriented overview of the issues involved in launching and running political deliberation systems, summarizing the main problems and offering potential solutions. We argue that these issues can be summarized under four main headings: stakeholder engagement, Web platform design, service management, and political process reshaping.

1. Stakeholder engagement: Governmental deliberation systems are not commercial ventures that can be measured by return on investment; instead, they exist to offer politicians and citizens a service. An important measure of success is therefore the extent of user involvement.

2. Web platform design: The Web site is the principal element of the service and also the medium for deliberation. Its design is therefore a nontrivial issue. Even the adaptation of a conventional hierarchical threaded discussion forum poses problems for its designers, and understanding and supporting the structure of deliberative argument through technology is an emerging research area.

3. Service management: Although many initiatives focus on getting a Web site up and running, the continuing management and evolution of the service often prove the more serious challenge. There are many issues concerned with moderation of the discussion, facilitating the community undertaking it, and managing the content that is generated.

4. Political process reshaping: Virtually the only advantage that government-driven deliberative systems have over the many opportunities for discussion currently available on the Internet is the ability to explicitly connect the deliberation with the political process. Few initiatives take these possibilities seriously by addressing political outcomes beyond the deliberation itself.

We use these four headings to report the current state of knowledge in the existing literatures, and later to structure the analysis of our case: the Norwegian Demokratitorget (Democracy Square). We use insights from the theoretical study to analyze our case, and combine both literature and case analyses to derive a detailed summary of the issues confronting government institutions in setting up and running deliberative systems.

\section{DESIGN AND MANAGEMENT OF POLITICAL DELIBERATION SYSTEMS}

In this section we examine the existing theoretical literature to identify factors influencing the design and management of deliberation systems.

\section{Stakeholder Engagement}

Political deliberation in this context is often characterized as a dialogue between two stakeholder groups: politicians and citizens. The focus is on the interaction between the two groups (Hudson-Smith et al. 2005; Chadwick 2003). Both are often treated as if they were homogenous stakeholder groups with uniform characteristics. However, young people are addressed specifically by some discussion forum projects (Macintosh et al. 2003; Rose and Sæbø 2005; Finn and Detlor 2002). The limited success of these youth projects is explained by the failure to engage young people by allowing them to influence political decisionmaking (Masters et al. 2004) and young peoples' lack of identification with the style and structure of political debate (Macintosh et al. 2003).Engagement of citizens presupposes a critical and deliberative background political culture (Biasiotti and Nannucci 2004) and a willingness to take ownership of local policy making (Callanan 2005). Education may therefore play an important role.

Deliberative systems are often regarded as an opportunity to promote participation and civic engagement to a wider audience, often at the local level (Macintosh et al. 2003). Access to technology is one major factor affecting the democratic potential of the Internet (Ranerup 1999). Where individuals have unequal access to technology (based on location, gender and class), deliberative systems may be dominated by citizens' groups already privileged in the democratic discourse (Jensen 2003; Papacharissi 2002). A more optimistic perspective argues that if access can be granted to more citizens, participation will follow (Ainsworth, Hardy, and Harley 2005).

Further accessibility concerns reflect the cost of Internet use (Olsson et al. 2003), language (Olsson et al. 2003), and policy information transparency (Bekkers 2004). User skills and individual competence are found to be prerequisites for discussion forums that function well (DiMaggio et al. 2001; Olsson et al. 2003). Competence is needed to use ICT in general (Olsson et al. 2003), to understand the rationale behind the technology (Ranerup 1999), and to screen and interpret large amounts of online information (Stanley and Weare 2004). Since such competence is unequally distributed, initiatives run the risk of attracting technophiles, more interested in appearance than function 
(Macintosh et al. 2003), or of making the information rich richer (Stanley and Weare 2004).

Jansen and Kies (2005) argue that citizens' motivation to participate is dependent on assumed political impact. Such impact is not present if government officials' or politicians' participation is limited or nonexistent. The presence of politicians is found to contribute to a respectful tone and to factuality in debates, even though they may use debate forums for their own purposes (e.g., election campaigning; Jensen 2003). Rose and Sæbø (2005) investigated politicians and citizens roles in more detail, and found that citizens engaged in discussions to set agendas and influence political decision making, whereas politicians demonstrated their specialist expertise through argumentation and election campaigns, and therefore argue that both sets of interests needs to be accommodated in online communities. Jensen (2003) argues that the presence of individual politicians at a deliberation space was a major reason for its success.

\section{Web Platform Design}

There is wide agreement that the design style of the discussion forum influences its outcomes, particularly deliberation form and style, and willingness to participate (Aikens 1998; Carlitz and Gunn 2002). However, there is currently little research on design. Dutton and Eynon (2009) criticize initiatives for being too top-down and institutioncentric, where the design is predefined by the initiators (the government) to provide information to citizens, without adapting more dynamically oriented approaches involving participation-oriented tools and practices, to support bottom-up innovations from active, participation-oriented citizens. Discussion categories can be predefined or established dynamically. Predefining directs discussion in specific directions, whereas user-defined threads increase ownership and flexibility. Dialogue forms (e.g., question and answer) can also be determined in design. Janssen and Kies (2005) focus on the choice between synchronous and asynchronous dialogue:

\footnotetext{
It is fundamental to distinguish the real-time discussion spaces (chat rooms) from the asynchronous online discussion spaces that do not have time constraints (e-mail list; newsgroups; Bulletin boards; forums). It is generally recognized that the former are spaces of encounter that attract "small talk" and jokes, while the latter constitutes a more favourable place for the appearance of some form of rationalcritical form of debate since it allows participants to spend more time to think and justify their interventions. (321)
}

Identity management design can favor anonymity or identification control. Anonymity can be challenging, since it may heighten the level of extremist and hate speech (DiMaggio et al. 2001). However, Koch (2005) argues that anonymity could be seen as an opportunity to increase deliberation quality since the debaters are no longer tagged by traditional markers such as age, sex, and race. Identification control may increase the entrance threshold (by requiring some kind of registration), but may improve quality, accountability, and the obligation to participate and respond (Janssen and Kies 2005). Citizen ownership is thought to promote engagement and trust in government (Callanan 2005), and can be encouraged by including citizen groups in the design and development of the system (Macintosh et al. 2003).

\section{Service Management}

Most discussion spaces have some degree of moderation that may influence deliberative outcomes. Moderation may have considerable influence on the topics under discussion and the style of dialogue and can limit the role for dissenting voices (Ainsworth, Hardy, and Harley 2005). It can restrict ownership of agenda setting and the decentralized definition of topics (Janssen and Kies 2005). Moderation may be occasional-limited to discouraging flaming outbursts and soothing overheated debates (Carlitz and Gunn 2002) —or more pervasive. Moderation may, however, be resented by debaters, and risks becoming conscious or unconscious political censorship. Nevertheless, Jensen (2003) argues that a high level of active moderation can lead to an improved quality of argumentation.

Citizen ownership of service management may also influence the building of engagement and community, since technology effects reflect active choices made on the basis of its owners' interests and cultural norms (DiMaggio et al. 2001). Bekkers (2004) argues that it is important to include citizens and other stakeholders in the initiating phase to achieve commitment and ownership. However, it is equally important to allow for the self-organization and evolution of the online content (Bekkers 2004). Feedback to deliberators is important if deliberation results are to be seriously considered by policymakers. Macintosh et al. (2003) describe how, in the deliberative system under consideration, young people receive feedback on how their contributions are relayed further in the decision-making process.

\section{Political Process Reshaping}

Political deliberative systems are intended to connect in some fashion with the political process. Discussion forums often have little formal role in the policymaking cycle but act as arenas for free public debate (Hill 2003; Paolillo and Heald 2002) or channels for social movements or oppositions (Fung 2002). There is little evidence that freestanding discussion forums impact policymaking; however, the existence of a public sphere 
alongside the one-sided official truths of totalitarian or semitotalitarian societies may represent an indirect voice in decision making (Fung 2002).

Deliberation can be consultative or informative without challenging the traditional roles of politicians as decision makers and citizens as voters (Päivärinta and Sæb $\varnothing$ 2006). Citizens may be asked to submit suggestions to the public authorities (Aidemark 2003), dialogue may be initiated for the purpose of teaching inhabitants how to become e-citizens (Biasiotti and Nannucci 2004), or citizens can be given the opportunity to communicate with representatives and government officials (Nugent 2001). Discussion forums can be a communication channel supporting feedback to bureaucracies (Ainsworth, Hardy, and Harley 2005), politicians (Papacharissi 2002), political institutions (Papacharissi 2004), and other policymakers (Biasiotti and Nannucci 2004) or decision makers (Sæb $\varnothing$ and Päivärinta 2005). Papacharissi (2002) points out that that the ability to provide politicians with direct feedback does not guarantee influence over policy formulation. Citizen input can also be more explicitly and directly connected to decision-making processes (Held 1996; Pateman 1970). Politicians and citizens share an interest in dialogue and discourse leading to the formation of political opinion, and the open display of deliberation legitimizes the exercise of power. Discussion forums can be used as an interactive channel for policymaking (Bekkers 2004). Several motives can be discerned for interactive policymaking, including involving (otherwise disenfranchised) young people (Macintosh et al. 2003), bridging the cleavage between politics and administration, achieving acceptance for policies among relevant stakeholders, and enhancing the quality of policy formulation (Bekkers 2004). Although the opinions of online debaters mirror those of their offline counterparts, interactive policymaking may shake up prevailing relationships within policy networks and introduce new voices (Stanley and Weare 2004).

\section{Summary}

The main thrust of the available literature is summarized in table 1.

\section{RESEARCH METHODS}

This section presents the research strategies used in the collection and analysis of data, in the development of theoretical frameworks and constructs, and in the derivation of results and conclusions.

Case studies are the research strategy of choice when "how" questions are posed (how do you design and manage deliberative systems?), where the researcher has little control over actual behavioral events, and where the focus is on "a contemporary phenomenon within some real-life context" (Yin 1994). Benbasat et al. (1987) consider case studies particularly appropriate for sticky, practice-based

TABLE 1

Existing understandings that inform the design of deliberation systems

\begin{tabular}{|c|c|}
\hline Parameter & Understanding \\
\hline Stakeholder engagement & $\begin{array}{l}\text { - It is important to involve major stakeholder groups (often citizens and politicians) throughout } \\
\text { the project. } \\
\text { - Deliberation systems can be targeted at engaging participants new to political debate. } \\
\text { - Competence and access are important prerequisites. } \\
\text { - Citizen motivation to participate is dependent on assumed political impact. }\end{array}$ \\
\hline Web platform design & $\begin{array}{l}\text { - Predefined categories may lead discussions in a specific direction, whereas dynamically } \\
\text { developed categories increase ownership and flexibility. } \\
\text { - Synchronous debates encourage short discussions, whereas asynchronous systems can host } \\
\text { more reflective and well-argued debates. } \\
\text { - Anonymity decreases the entry threshold, but can lead to less reflective (sometimes extreme) } \\
\text { contributions, whereas strict identity control increases deliberation quality, but can provide } \\
\text { an entry barrier. }\end{array}$ \\
\hline Service management & $\begin{array}{l}\text { - The degree of moderation and censorship influences the deliberation outcome. } \\
\text { - It is important to include citizens and other stakeholders in service management to develop } \\
\text { stakeholder ownership. }\end{array}$ \\
\hline Political process reshaping & $\begin{array}{l}\text { - Deliberation can serve different roles in the political process and it is important to be specific } \\
\text { about its role and objectives. } \\
\text { - Political processes should be redesigned to involve online activities if achieving real influence } \\
\text { is a priority. }\end{array}$ \\
\hline
\end{tabular}


information system (IS) problems where research and theory are at their early formative stages. A longitudinal strategy is chosen, since it facilitates observation and preliminary evaluation of the effects of design and management decisions. The single case strategy is dictated by limited availability and access to similar projects; however, the case is considered "typical" (Yin 1994), inasmuch as it shares many points of similarity with the other cases documented in the literature. The similarities include: a regional government sponsor, project organisation, an external developer, focus on developing the software, limited engagement of citizens and politicians, and difficulties in managing the site once implemented.

The research follows a multiple data collection, multiple analysis strategy. The data were collected over a period of twenty-eight months - from winter 2003 to fall 2005using multiple methods. This period covers the initial genesis and development of the discussion forum Demokratitorget, its implementation and use (particularly during the run up to the local election in fall 2003), an intervening period where it fell into disuse and was temporarily discontinued, and its evaluation and relaunch in 2005. One of the authors was a participant observer (following the project meetings) throughout this period. Data collection methods included: direct and participant observation of the project and its steering committee, project documents study, fifteen semistructured interviews of politicians and administrators, system observation, transcription of project e-mail conversations (e.g., with the system vendor), and recording of citizens' and politicians' postings on the debate forum. The data collection triangulation here involves the consideration of design and management decisions and their effects from three perspectives: those of the project team, those of the users, and by direct observation of the systems itself-particularly the communicative discourse recorded in the system by its users. Data were recorded as audio recordings and transcriptions, project agendas, minutes and notes, project design and specification documents, evaluation reports, stakeholder validation summaries, e-mail collections, phone conversation notes, the complete collection of postings on the forum during the 10 months period it was up and running, and interview notes and transcriptions.

Four analyses of the data sources were undertaken. A textual content analysis of the contributions posted in the discussion was conducted to understand the shape and significance of the deliberative activity (the postings) at the forum (Rose and Sæbø 2005; Sæb $\varnothing$ 2006; Sæb $\varnothing$ and Päivärinta 2005). Genre analysis was used to deepen this understanding and to relate it to design and management considerations (Rose and Sæbø 2005). Democracy Square was written up as a conventional narrative case study in Sæbø's (2006) PhD thesis, where the events, actors, and eventual progress of the project were described, ordered,

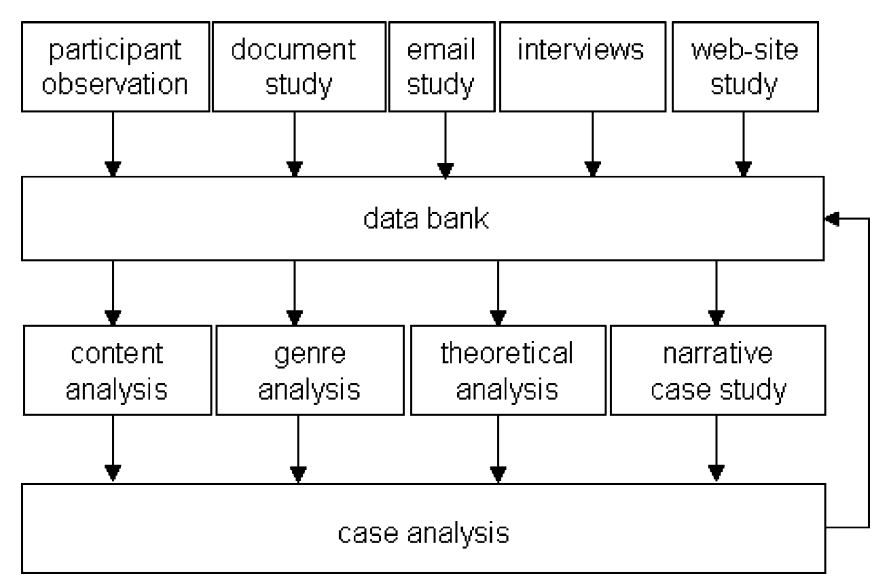

FIG. 1. Research process.

and related. The narrative was used to focus the analysis on design motivations and decisions and their consequences, giving a structure for the consideration of cause and effect. The final analysis was theoretical: Stakeholders' perspectives were scrutinized in relation to different models of democracy (Päivärinta and Sæbø 2006). This analysis contributes to a broader understanding of the overall democratic and societal goals of this kind of project, and how they are implemented in software applications and deliberative processes. The methodological approach is represented in figure 1.

The case analysis presented in the next section draws on elements of all of the four analyses.

\section{DEMOKRATITORGET}

In 2003 the Norwegian Ministry of Labor and Social Inclusion granted funding for Demokratitorget-a project designed to foster electronic dialogue between politicians and citizens. Demokratitorget was intended to encourage electors to influence decision making, legitimize the autonomy of the region, and reverse declining election participation. The project was launched seven months before the local and regional elections.

The project group signed a contract for the development of the site with a local software firm experienced in e-democracy software implementation. The contract was agreed without formal call for tender. Time constraints forced the project group to move directly to consideration of technical concerns, without really discussing the overall deliberative objectives for the project. The prototype was introduced to the project group less than five weeks before it was launched; technical flaws remained, further development was required, and the design was not discussed further before its launch. The principal feature of Demokratitorget was its discussion board, where citizens and politicians could initiate and participate in themed 
debates. The site opened in August 2003, and activity peaked at the local election, declining to little or nothing thereafter. Several factors suggest that Demokratitorget was only partially successful. Politicians and citizens had different motives for participating - in broad terms, politicians tried to profile themselves for the coming election, whereas citizens tried to gain influence over policy for specific issues that concerned them (Rose and Sæbø 2005). Neither of these purposes was particularly well supported by the platform offered. After the election the platform was little used and citizens' contributions failed to stimulate further debate. The project was suspended after ten months of appearance, and entered a phase of evaluation, reconsideration, and discussion of relaunch.

In the rest of this section we examine the Demokratitorget experience with respect to our four themes and the literature summaries developed earlier.

\section{Stakeholder Engagement}

From the literature review:

- It is important to involve major stakeholder groups (often citizens and politicians) throughout the project.

- Deliberation systems can be geared to engaging participants new to political debate.

- Competence and access are important prerequisites.

- Citizen motivation to participate is dependent on assumed political impact.

In the development phase the project group discussed strategies for encouraging stakeholders to participate. Young people were considered a target group, and the project group discussed which services would appeal to them-though without consulting any prospective users. Project members understood that they were therefore "on thin ice" in these discussions. Marketing material was distributed through the school system, but not to further education students - an omission later considered to be a reason for the limited success (Sæbø 2006). A plan to involve young people as moderators and editors was shelved due to time constraints. The commitment of a second major stakeholder group, politicians, was assumed. Little attention was paid to motivating them; however, they were kept informed of progress, and were offered training in how to use the system. One-third of the participants were politicians, writing half of the postings. However, the politicians posted only two (out of sixty-nine) contributions after the election. Politicians complained that is was difficult to keep up with the discussions taking place in various different categories, and that Demokratitorget came on top of everything else they were supposed to do:

Politicians have an obligation to participate wherever politics is discussed. But we also have to continue with other activities, like participating in traditional debates and meeting citizens in the city center. (interview with politician, June 15, 2003)

Demokratitorget's principle target group was young people between eighteen and twenty-two years of age. The project group considered that young people were underrepresented in the existing political system, did not participate in traditional deliberation fora, and were extensive users of Internet-based technologies. Later analysis revealed that although 46 percent of the active participants were below thirty years old, only two of the ten most active users (responsible for around half of all postings) were below twenty-five years old. The tone and style of the discussions indicated that these participants were well informed, familiar with political debate, and active in other contexts.

Both access and competence were assumed in the case of young people, and there were no training activities. Although training was offered to politicians, the acceptance of this offer was low. Both citizens and politicians expressed concerns about the structure of the discussions, and commented on the difficulty of using the system, suggesting some mismatch between user competence and design.

It is difficult. . . . If you want to know if there are any questions concerning (my party) or myself, you need to look through all the categories. . . How on earth could I follow all the discussions? (interview with politician, June 17, 2003)

Minor access problems (delay) caused by initial server difficulties caused considerable irritation:

The system is so slow; I can't stand waiting for a response. It takes hours to respond when you click ... the server might as well be located in China. It's a pity, since Demokratitorget could have been a wonderful tool for politicians to communicate with citizens. (citizen, post, Demokratitorget, September 2, 2003)

There was also a concern about a more generalized, generational lack of competence:

The biggest problem with politics and the Internet is you politicians' lack of competence in using the Internet to meet your electors. When the young people of today whose second home is the Internet become politicians, then, my friends, if you have not learned how to use a computer, you're out! Decisions will be made here [online] by everybody in places much more visible than today's closed circles. And you, my friends, will have no chance at all to influence decisions. (citizen, post, Demokratitorget, August 30, 2003)

Demokratitorget was intended to involve citizens more directly in political decision making. Analyses of the postings identify a mismatch between the expectations of citizens and of politicians. Whereas citizens want to influence policy, politicians prefer to inform and to market their own political views, at least before an election (Rose and Sæbø 
2005). A commentator summed up this mismatch in the discussion of democracy and the Internet:

Dialogue is important. However there will be a problem if it turns out that the political candidates don't take it [Democracy Square] seriously, but just consider it a kind of "exercise" in democracy. (citizen, post, Demokratitorget, August 28, 2003)

Citizens were disappointed by the absence of politicians in the discussion and by the politicians' commitment to listen and debate:

I'm incredibly disappointed by the activities at these pages. It is reasonable to believe that politicians will discuss major topics and post contributions. Now we, the voters, are the active parties. I start to wonder; are you politicians similarly passive as elected representatives as well? The word "disdain" comes to mind. (citizen, post, Demokratitorget, September 30, 2003)

\section{Web Platform Design}

From the literature review:

- Predefined categories may lead discussions in a specific direction, whereas dynamically developed categories increase ownership and flexibility.

- Synchronous debates encourage short discussions, whereas asynchronous systems can host more reflective and well-argued debates.

- Anonymity decreases the entry threshold, but can lead to less reflective (sometimes extreme) contributions, whereas strict identity control increases deliberation quality, but can provide an entry barrier.

The Democracy Square forum was set up with twentyfive predetermined discussion categories chosen from suggestions made by the software developers, without flexibility to dynamically develop new categories. Some forum discussions ended up confused about which category they fitted in, with the categories making it difficult for contributors to figure out what was going on:

Because of all the categories I need to check every day in every category, which is quite laborious. ... Unwieldiness is a way to exclude users. I started to look through everything yesterday; by the end fourteen categories were still left. (interview with politician, September 1, 2003)

A convention that was built into the site, along with hierarchical thematic threads, was the question-and-answer principle. Some contributors took this to mean that citizens should ask questions, which politicians should answer. A direct response to an earlier contribution was labeled "answer" by the software irrespective of its actual role in the dialogue. Contributors took up this principle and formulated many of their postings in this form, but using it for many different ends: sometimes to encourage new contri- butions, sometimes to change the subject, sometimes to close down an uncomfortable subject.

Demokratitorget used asynchronous debates. This debate attracted both short and longer postings, varying from 6 words to 1,400. Citizens were sometimes unhappy that politicians (or other contributors) replied slowly or not at all. The asynchronous form gives greater freedom in selecting which postings to respond to and how to respond:

I prefer the opportunity to choose what to respond to and what I can't use my resources on. (interviewed politician)

Participants at Demokratitorget registered using their real names (although no identity controls were conducted), but could choose to use an alias in the discussion. Users could thus maintain anonymity in the discussions, but could be traced by a site manager if necessary. The vast majority used their own names and there was some discussion of whether anonymity should be allowed. Anonymous postings were sometimes received with suspicion:

\footnotetext{
I can't say I appreciate the way you are making your point, using unserious characterizations, staying anonymous without the guts to stand up for your own opinions. (politician, name given, post, Demokratitorget, September 2, 2003)

Yesterday I saw one of these anonymous maniacs who said something about how ridiculous this discussion forum is. It's impossible to discuss with these silly people who stay anonymous. I can't see why we should spent time on them. (interview with politician, September 2, 2003)
}

\section{Service Management}

From the literature review:

- The degree of moderation and censorship influence the deliberation outcome

- It is important to include citizens and other stakeholders in service management to develop stake holder ownership.

Some of the early debate in this forum concerned the practical operation of the forum, both at the technical level (some complaints about navigation speed) and at the level of use policy and social conventions. One contributor was enraged that some of his critical comments were posted but never displayed - he assumed they had been censored. The discussion board moderators denied this (while retaining the right to censor "inappropriate" material). It remained unclear what happened to the offending messages. An etiquette question arose over the question of how challenging, rude, or offensive a contribution could be, and many contributions tried to impose limits-often replying to an offender with a direct reference to those limits: "I can't really say that I appreciate your way of making your point, but ..." (politician, full name, post, Demokratitorget, August 25, 2003). 
Service management was conducted by the vendor and public administrators, in cooperation with the project group. Neither politicians nor citizens were included. Control of the site by public servants became an issue with politicians:

It is problematic that administrators set the framework for what is discussed, thus influencing the political agenda. In a democratic system politicians are responsible for the political agenda, bureaucrats administer it. This is a critical weakness in the way Demokratitorget is organized. (interview with politician, September 2, 2003)

There was some discussion about improving the forum. Politicians asked for notifications when questions or comments were added concerning themselves or their party, since it took a lot of effort to check all the categories for relevant topics. A clear question-and-answer section was suggested.

\section{Political Process Reshaping}

- Deliberation can serve different roles in the political process and it is important to be specific about its role and objectives.

- Political processes should be redesigned to involve online activities if achieving real influence is a priority.

Content analysis of the postings identified conflicting interests between politicians and citizens. Politician seemed to focus on a desire to demonstrate expertise in political matters to a broad range of voters. Citizens seemed more interested in engaging politicians in discourse to set agendas, influence political decision-making and affect election results. The analysis showed that only a few conversations aligned both politicians' and citizens' interests such that the needs of both groups could be served. A wide range of contributors mentioned the difficulty of getting the right people to participate and complained about the absence of, variously, politicians in general, contributors from one particular region, the young, and senior elected officials.

The politicians interviewed were more motivated by the idea of influencing others and marketing their political viewpoints than by themselves being influenced by listening to ongoing debates. A major concern was the quality and representativeness of the arguments, making it difficult for politicians to judge the usefulness of the online debates. Politicians tended to react defensively to aggressively phrased or seemingly unreasoned arguments, and to avoid debates on sensitive topics where they could easily be exposed or criticized or had no easy solution. However, the project group made no serious attempt to identify how the discussion could or should be integrated
TABLE 2

Summary of case analysis

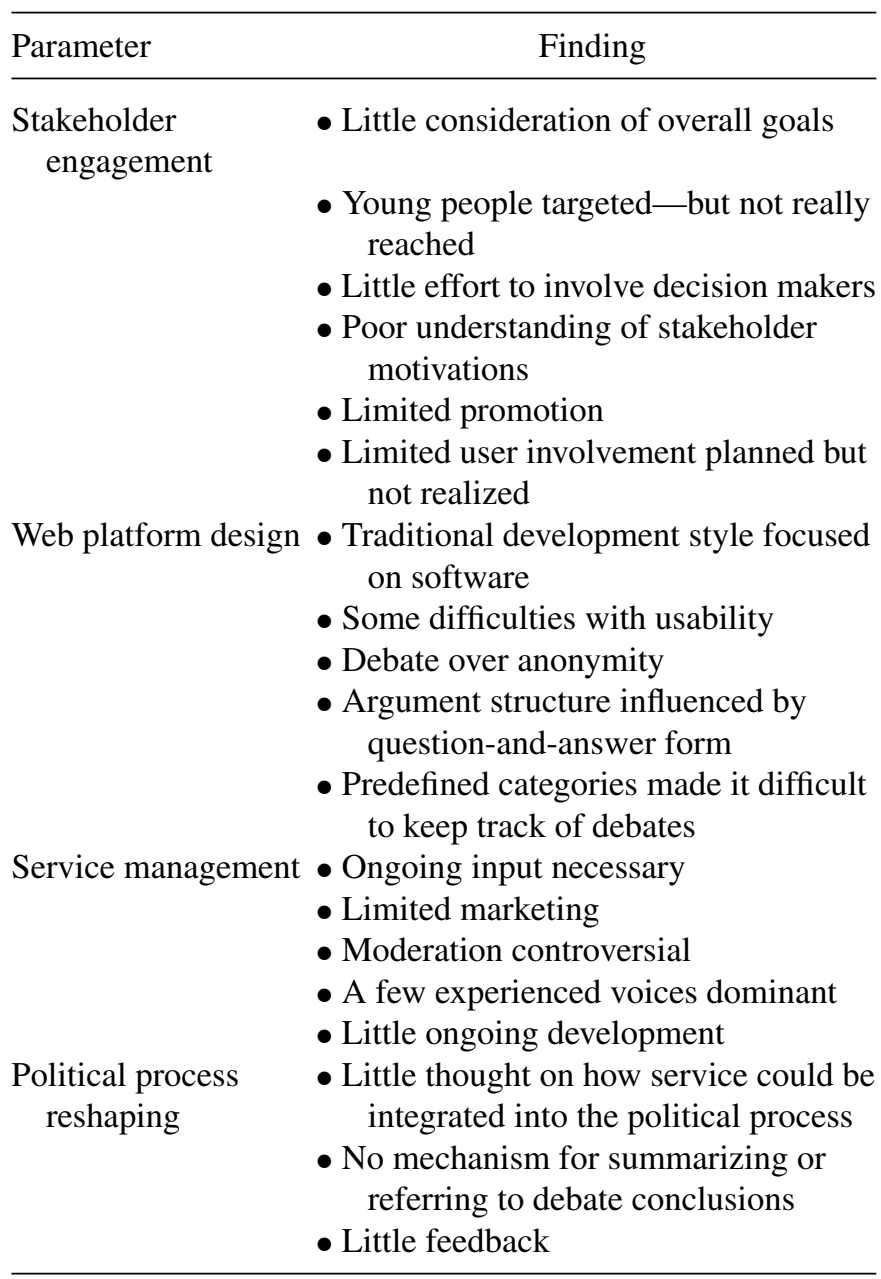

into the region's political process, seeming to assume that deliberation was, in itself, the project's objective.

The major issues from the case analysis are sumarized in table 2.

\section{KEY ISSUES IN ESTABLISHING POLITICAL DELIBERATION SYSTEMS}

In the section we revisit each of the four principal areas to elaborate the major issues involved for governments in implementing deliberation systems. We integrate insights from both literature and case analysis (table 3 ) to provide a (partially normative) summary of what is currently known about the design and management of political deliberation systems.

\section{Stakeholder Engagement}

Construction of a Web site does not, in itself, encourage deliberation, increase citizen commitment to political 
TABLE 3

Summary of insights from literature and case study

\begin{tabular}{|c|c|c|}
\hline Parameter & From literature & From case study \\
\hline Stakeholder engagement & $\begin{array}{l}\text { - It is important to involve major stakeholder groups (often } \\
\text { citizens and politicians) throughout the project } \\
\text { - Deliberation systems can be targeted at engaging } \\
\text { participants new to political debate } \\
\text { - Competence and access are important prerequisites } \\
\text { - Citizen motivation to participate is dependent on assumed } \\
\text { political impact }\end{array}$ & $\begin{array}{l}\text { - Little consideration of overall goals } \\
\text { - Young people targeted-but not really } \\
\text { reached } \\
\text { - Little effort to involve decision makers } \\
\text { - Poor understanding of stakeholder } \\
\text { motivations } \\
\text { - Limited promotion } \\
\text { - Limited user involvement planned but } \\
\text { not realized }\end{array}$ \\
\hline Web platform design & $\begin{array}{l}\text { - Predefined categories may lead discussions in a specific } \\
\text { direction, whereas dynamically developed categories } \\
\text { increase ownership and flexibility } \\
\text { - Synchronous debates encourage short discussions, } \\
\text { whereas asynchronous systems can host more reflective } \\
\text { and well-argued debates } \\
\text { - Anonymity decreases the entry threshold, but can lead to } \\
\text { less reflective (sometimes extreme) contributions, } \\
\text { whereas strict identity control increases deliberation } \\
\text { quality, but can provide an entry barrier }\end{array}$ & $\begin{array}{l}\text { - Traditional development style focused } \\
\text { on software } \\
\text { - Some difficulties with usability } \\
\text { - Debate over anonymity } \\
\text { - Argument structure influenced by } \\
\quad \text { question-and-answer form } \\
\text { - Predefined categories made it difficult } \\
\text { to keep track of debates }\end{array}$ \\
\hline Service management & $\begin{array}{l}\text { - The degree of moderation and censorship influences the } \\
\text { deliberation outcome } \\
\text { - It is important to include citizens and other stakeholders in } \\
\text { service management to develop stakeholder ownership }\end{array}$ & $\begin{array}{l}\text { - On-going input necessary } \\
\text { - Limited marketing } \\
\text { - Moderation controversial } \\
\text { - A few experienced voices dominant } \\
\text { - Little ongoing development }\end{array}$ \\
\hline Political process reshapin & $\begin{array}{l}\text { - Deliberation can serve different roles in the political } \\
\text { process and it is important to be specific about its role } \\
\text { and objectives } \\
\text { - Political processes should be redesigned to involve online } \\
\text { activities if achieving real influence is a priority }\end{array}$ & $\begin{array}{l}\text { - Little thought to how service could be } \\
\text { integrated into the political process } \\
\text { - No mechanism for summarizing or } \\
\text { referring debate conclusions. } \\
\text { - Little feedback }\end{array}$ \\
\hline
\end{tabular}

participation, or build a community. Deliberation systems are in tough competition for users' Internet attention and, without sustained effort in engaging participants, are likely to struggle.

- Establishing deliberation goals: Focused deliberation goals make many other design decisions easier. For example, which policy area or areas are involved? What are the desired outcomes in terms of deliberation quality, involvement in decision making, extension of deliberative participation to particular groups, greater volume of participation, and/or social capital effects?

- Identification of user groups: Deliberation systems normally need to target particular citizen groups by, for example, issue (health, environment), region, age (young people), professional background (farmers, engineers), social status, education, or other characteristics.

- Involvement of politicians, government, and administrations: An effective way to design a deliberation system is as a dialogue between those who govern and those who are governed. This implies consideration of which politicians and administrators should be involved and how they will be recruited.

- Stakeholder motivation and participation incentives: Stakeholders and user groups may have different motivations for participation. For example, politicians often need opportunities to profile themselves or their parties, whereas citizens may primarily seek influence in the policymaking process. These different motivations need to be understood and incentives and rewards for participation (perhaps in terms of 
greater influence or exposure) need to be built into the service.

- Outreach and promotion: A program of active recruitment of users through other media will usually be necessary, through advertising, media coverage, or search-engine profiling.

- User-ownership and self-organization: Stakeholder engagement is promoted by the transfer of elements of control and ownership (including control of deliberation content and process) to participating communities. Control of agenda setting is an important issue, because citizens do not always respond to government agendas, have issues of their own, and are sensitive to potential manipulation and censorship.

- Information support and competence development: The provision of factual background information and expert opinion supporting deliberation and political decision making may be necessary, as may training of minority groups in democratic process and use of web applications.

\section{Web Platform Design}

Deliberation systems go through an initial development phase where software is designed and programmed. The following issues need to be addressed.

- User-led evolutionary development: Overcentralised traditional development methods can be problematic because of the need to generate citizen engagement, and to accurately reflect citizens' evolving concerns. Procedures for tool development in dialogue with, or under the control of, users and stakeholders should be investigated. Some iterative development based on feedback from practice is also normally required, to address the need for bottom-up innovations from active citizens.

- Optimal usability: Deliberation systems need to achieve high standards of usability to include different citizen groups in a representative way. This may involve interfaces targeted at different levels and styles of technology competence.

- Open access for all: Deliberation exercises risk favoring the already privileged technology-literate elite, and can be invalidated if they are unrepresentative. Therefore, tools need to be designed with a wide spectrum of potential users in mind, with different social, cultural, economic, and technical backgrounds. Open access design may include:

- Disability adaptation: accessibility features for people with special needs or disabilities.

- Language support: enabling deliberation in multicultural situations.
- Communication media and channel choice: the choice of synchronous or asynchronous deliberation through text, voice, or video delivered by conventional paper, phone, Web, mobile, SMS, live camera or digital television, or some appropriate combination of these.

- Identity management: A key element of identity management is the anonymity policy-whether users should be identified by their real identities or not. Privacy protection is also an important consideration in all government sites.

- Deliberation structure design: Deliberation can be understood as a process, which a deliberation system at least partially structures. The adoption of a hierarchical, thematically threaded discussionboard technology imposes a particular deliberation process structure on its users, enabling some forms of interaction and constraining others. However, there are many choices for structuring deliberation, argumentation, negotiation, and decision making, which have consequences for the shape and style of deliberation and for what content can later be recovered and interrogated.

- Data structure design: Similarly, the content of deliberation can be regarded as data that can also be stored in many ways - as free text or more structured inputs, for example, keywords, smiley or Likert evaluation, text fields, or categorization schemes. Data structure design has a large influence on which data can later be easily searched and retrieved.

\section{Service Management}

A deliberation system can be understood as a piece of software embedded in a set of organisational procedures (or a computer system embedded in an information system), for which the whole represents a service to the user community. Here, we consider challenges in the ongoing management of the service.

- Conditions of operation and maintenance: The operation of the service needs to be funded-by grant, by donation, by selling services or advertising, or by some combination of these. The site must be maintained and updated, and someone must act as Web master and sometimes as intermediary between the service and decision makers.

- Implementation and launch: Implementation and launch involve target-group marketing and media coverage, establishing a working tool and service, piloting the tool, and building up a critical mass of users, or community.

- Moderation: Most deliberation systems are moderated - they develop formal and informal policies for which online behaviors and content are 
tolerated and its monitoring. They also often offer facilitation of online participation and conflict mediation.

- Representation: Ensuring representative use includes the recruitment of underrepresented stakeholder groups, ensuring fair and balanced access, and antidominance strategies (such as upper limits for contributions from the same participant).

- Dynamic evolution: The management of the service must also include its evolution to reflect user feedback, technology advances, and current trends and issues.

\section{Political Process Reshaping}

Government-driven deliberation systems need to consider the integration of the service with policymaking.

- Governance process analysis and redesign: Government bodies need to understand how the service will be integrated into the existing political process, and into offline deliberation. Accommodating inputs from deliberation may eventually involve altering the legislative framework. It is normally important for service users to understand how their contributions will affect future decision making.

- Power-sharing strategies: Integration of widespread deliberation into the political process implies some (potentially controversial) redistribution in the power balance between citizens, government officials, and elected representatives - normally a move toward a more direct form of governance.

- Deliberation content analysis and referral: Analyzing the results of deliberation is time-consuming and complex, particularly in large-scale free-text situations, and may require automation. Where a cumulative message can be understood, it is important that elected officials receive it—and at the appropriate point in their considerations.

- Feedback and response: Short-term and long-term feedback to contributors is also important. Shortterm feedback involves presenting aggregated results of deliberation back to participators, whereas long-term feedback involves ensuring that they understand its influence on policymaking.

We have here adopted a largely practical focussynthesizing current state-of-the-art understandings with our own experiences of Demokratitorget. The results of these considerations are organized under four headings: stakeholder engagement, Web platform design, service management, and political process reshaping. We indentified twenty-five issues (see table 4) that we believe to be critical for government institutions commissioning deliberations. In some cases we are also able to of-
TABLE 4

Major issues in establishing deliberation systems

\begin{tabular}{|c|c|}
\hline Parameter & Issue \\
\hline Stakeholder engagement & $\begin{array}{l}\text { Establishing deliberation goals } \\
\text { Identification of user groups } \\
\text { Involvement of politicians, } \\
\text { government, and } \\
\text { administrations } \\
\text { Stakeholder motivation and } \\
\text { participation incentives } \\
\text { Outreach and promotion } \\
\text { User-ownership and } \\
\text { self-organization } \\
\text { Information support and } \\
\text { competence development }\end{array}$ \\
\hline Web platform design & $\begin{array}{l}\text { User-led evolutionary } \\
\text { development } \\
\text { Optimal usability } \\
\text { Open access for all } \\
\text { Identity management } \\
\text { Deliberation structure design } \\
\text { Data structure design }\end{array}$ \\
\hline Service management & $\begin{array}{l}\text { Conditions of operation and } \\
\text { maintenance } \\
\text { Implementation and launch } \\
\text { Moderation } \\
\text { Representation } \\
\text { Dynamic evolution }\end{array}$ \\
\hline Political process reshaping & $\begin{array}{l}\text { Governance process analysis and } \\
\text { redesign } \\
\text { Power sharing strategies } \\
\text { Deliberation content analysis and } \\
\text { referral } \\
\text { Feedback and response }\end{array}$ \\
\hline
\end{tabular}

fer some normative advice to researchers, students, and practitioners.

\section{CONCLUSION}

In this article we investigated design, implementation, and management processes for the development of political deliberation systems. We believe these considerations to be important because of the (as yet largely unrealized) potential these types of system have for transforming and revitalizing our democracies. Deliberation systems hold the potential to extend and improve dialogue between those who govern and those who are governed, to help understand public opinion, to increase citizen engagement in government, and, eventually, to influence the character of democracy. Governments understand their responsibility 
to provide these services (which are already widespread) but have difficulty prioritizing them in relation to those more traditional e-services that are ultimately intended to cut administrative costs. However, as so often happens with government technology adoption, governments are also likely to be under pressure from citizens who are increasingly used to expressing their opinions via the medium of the Internet and expect to be able to also use this medium in their interactions with government. Citizens are becoming networked individuals (Dutton and Eynon 2009), with various practices and tools allowing them to actively contribute in the development of online contents. Governments who really like to involve citizens thus really need to prioritize such services, adapting network-oriented tools allowing for dynamic development of online content, where citizens are invited as active contributors, not passive receivers.

Many governments have pilot projects and working systems in place, but these have usually small budgets, and projects are often focused on putting the basic technology in place, and not much beyond this. In general, governments have not yet understood how to compete with other Internet deliberation platforms, or their special relationship to the public in terms of deliberation services that are formally linked to the development and review of policy. Often these aspects are hardly considered, and it is assumed that the provision of a deliberation platform on the Internet is sufficient.

We would encourage researchers to take up some of the many issues that our study raises. An improved theoretical foundation might incorporate influences from political science (theories of deliberation and deliberative democracy), from social theory (perhaps the Habermas [1984] account of ideal speech and communicative action and theories of participation), from public governance theory, from communication studies, and from the many related research areas in information systems (e-participation, e-democracy, argument support, e-government, e-community, Web 2.0 and 3.0, social networking systems, etc.). We would also like to see rigorous action research projects in establishing deliberation systems (in which some of the more normative propositions of our work could be tested), the development of methodological and tool support for project workers and developers, the development of experimental test-bed platforms where design ideas could be developed, and also researcher-led evaluations.

\section{REFERENCES}

Aidemark, J. 2003. A knowledge perspective on e-democracy. Lecture Notes in Computer Science (2739):319-24.

Aikens, G. S. 1998. A personal history of Minnesota electronic democracy, 1994. Journal of Government Information 25(1):1-9.
Ainsworth, S., C. Hardy, and B. Harley. 2005. Online consultation: Edemocracy and e-resistance in the case of the development gateway. Management Communication Quarterly 19(1):120-45.

Avdic, A., K. Hedström, J. Rose, and Å. Grönlund, eds. 2007. Understanding eParticipation: Contemporary PhD eParticipation research in Europe. Örebro, Sweden: Department of Business, Economics, Statistics and Informatics, Örebro University.

Bekkers, V. 2004. Virtual policy communities and responsive governance: Redesigning on-line debates. Information Polity 9(3/4):193203.

Benbasat, I., D. K. Goldstein, and M. Mead. 1987. The case research strategy in studies of information systems. MIS Quarterly 11(3):36986.

Callanan, M. 2005. Institutionalizing participation and governance? New participative structures in local government in Ireland. Public Administration 83(4):909-29.

Carlitz, R. D., and R. W. Gunn. 2002. Online rulemaking: A step toward e-governance. Government Information Quarterly 19(4):389-405.

Chadwick, A. 2003. Bringing e-democracy back in - why it matters for future research on e-governance. Social Science Computer Review 21(4):443-55.

Coben, J. 2003. Deliberation and democratic legitimacy. In Debates in contemporary political philosophy: An anthology, ed. D. Matravers, and J. E. Pike, 342-59. London: Routledge.

Dahlberg, L. 2001. The Internet and democratic discourse: Exploring the prospects of online deliberative forums extending the public sphere. Information, Communication \& Society 4(4):615-633.

DiMaggio, P., E. Hargitta, W. R. Neuman, and J. P. Robinson. 2001. Social implications of the Internet. Annual Review of Sociology 27(1):307-36.

Dutton, W. H., and R. Eynon. 2009. Networked individuals and institutions: A cross-sector comparative perspective on patterns and strategies in government and research. The Information Society 25(3):198207.

Finn, K., and B. Detlor. 2002. Youth and electronic government: Towards a model of civic participation. Quarterly Journal of Electronic Commerce 3(3):191-209.

Fung, A. 2002. One city, two systems: Democracy in an electronic chat room in Hong Kong. Javnost-The Public 9(2):77-93.

Habermas, J. 1984. The theory of communicative action. Cambridge: Polity.

Habermas, J. 1999. Three normative models of democracy: liberal, republican, procedural. In Questioning Ethics: Contemporary Debates in Philosophy, eds. R. Kearney and M. Dooley, 135-144. London: Routledge.

Hagemann, C. 2002. Participation in and contents of two Dutch political party discussion lists on the Internet. Javnost-The Public 9(2):6176.

Held, D. 1996. Models of democracy. Oxford: Blackwell.

Hill, D. 2003. Communication for a new democracy: Indonesia's first online elections. Pacific Review 16(4):525-47.

Hudson-Smith, A., S. Evans, and M. Batty. 2005. Building the virtual city: Public participation through e-democracy. Knowledge, Technology \& Policy 18(1):62-85.

Janssen, D., and R. Kies. 2005. Online forums and deliberative democracy. Acta Politica 40(3):317-35.

Jensen, J. L. 2003. Virtual democratic dialogue? Bringing together citizens and politicians. Information Polity: The International Journal of Government \& Democracy in the Information Age 8(1/2):29-47. 
Koch, A. 2005. Cyber citizen or cyborg citizen: Baudrillard, political agency, and the commons in virtual politics. Journal of Mass Media Ethics 20(2/3):159-75.

Macintosh, A., E. Robson, E. Smith, and A. Whyte. 2003. Electronic democracy and young people. Social Science Computer Review 21(1):43-54.

Masters, Z., A. Macintosh, and E. Smith. 2004. Young people and e-democracy: Creating a culture of participation. Lecture Notes in Computer Science 3183:15-22.

Nugent, J. D. 2001. If e-democracy is the answer, what's the question? National Civic Review 90(3):221-34.

Olsson, T., H. Sandström, and P. Dahlgren. 2003. An information society for everyone? Gazette: The International Journal for Communication Studies 65(4-5):347-63.

Paolillo, J. C., and D. Heald. 2002. Democratic participation in the discursive management of usenet. Proceedings of the 35th Annual Hawaii International Conference on System Sciences (HICSS), 1040-1049.

Papacharissi, Z. 2002. The virtual sphere: The Internet as a public sphere. New Media and Society 4(1):9-27.

Papacharissi, Z. 2004. Democracy online: Civility, politeness, and the democratic potential of online political discussion groups. New Media \& Society 6(2):259-83.
Pateman, C. 1970. Participation and democratic theory. Cambridge: Cambridge University Press.

Päivärinta, T., and Ø. Sæbø. 2006. Models of e-democracy. Communication of Association of Information Systems 17(1):818-40.

Ranerup, A. 1999. Factors affecting discussions in on-line forums in local government. SIGGROUP Bulletin 20(2):11-13.

Rose, J., and Ø. Sæbø. 2005. Democracy squared: Designing on-line political communities to accommodate conflicting interests. Scandinavian Journal of Information Systems 17(2):133-68.

Stanley, J. W., and C. Weare. 2004. The effects of Internet use on political participation: Evidence from an agency online discussion forum. Administration Society 36(5):503-27.

Sæbø, Ø. 2006. Designing the e-democracy forum: Genres and models of e-democracy. PhD diss., Aalborg Univ. Denmark.

Sæbø, Ø., and T. Päivärinta. 2005. Autopoietic cybergenres for edemocracy? Genre analysis of a Web-based discussion board. HICSS. Proceedings of the 38th Annual Hawaii International Conference on System Sciences (HICSS), 98c.

Xenakis, A., and A. Macintosh. 2005. Trust analysis of the U.K. E-voting pilots. Social Science Computer Review 23(3): 312-25.

Yin, R. K. 1994. Case study research, design and methods (2nd ed.). London: Sage. 